\title{
ANALYSIS OF IMPLEMENTATION STANDARDS OF SHARIA MINIMUM SERVICES IN THE HOSPITAL \\ (Case Study at Sari Asih Sangiang Hospital 2018)
}

\author{
Fitri Yuli Mardiyati ${ }^{1}$, Dumilah Ayuningtyas ${ }^{2}$ \\ ${ }^{1}$ Hospitasl Administration, Faculty of Public Health, Universitas Indonesia, \\ Kampus Depok, Jawa Barat, 16425, Indonesia \\ ${ }^{2}$ Health Policy and Administration, Faculty of Public Health, Universitas Indonesia, \\ Kampus Depok, Jawa Barat, 16425, Indonesia \\ Email :v3.nabilah@gmail.com
}

\begin{abstract}
The development of sharia-based hospitals in Indonesia began with the Indonesian Islamic Health Effort Assembly (MUKISI) in collaboration with the National Sharia Council of the Indonesian Ulema Council (DSN-MUI) with the issuance of fatwa No. 107 / DSN-MUI / X / 2016 concerning Guidelines for Implementing Hospitals Based on Sharia Principles. One of them is Sari Asih Sangiang Hospital (RSSA) in the city of Tangerang, which has received sharia certification since 2018. Sharia hospitals guideline regulates Sharia Minimal Service Standards (SPM). The SPM contains regulations of reciting basmalah before procedures, hijab for patients and breastfeeding mother, mandatory training for patient's fiqh, Islamic education, gender-based ECG usage, using of hijab in the operating room, and scheduling elective surgery which not constrained by prayer times. This study uses a qualitative approach through report document review on the implementation of sharia quality indicators. The indicator format is determined by checklist, survey, medical record document; daily, monthly, and annual census recapitulation; secondary data from previous research, related literature, and in-depth interviews with correspondent criteria who responsible for implementing Sharia Quality at Sari Asih Sangiang Hospital. The results show that Sari Asih Sangiang Hospital has implemented Sharia SPM optimally, whose implementation refers to the standards and guidelines for the implementation of sharia hospitals issued by the DSN-MUI but is still constrained with the data recording problem. We suggest to put forward the need for coaching and training in Human Resources, and data recording should be done more regularly in order to maximize achievement targets.
\end{abstract}

Keywords: Implementation; Minimal Sharia Service Standards; Hospital.

Abstrak. Perkembangan rumah sakit berbasis syariah di Indonesia diawali dari Majelis Upaya Kesehatan Islam Seluruh Indonesia (MUKISI) bekerjasama dengan Dewan Syariah Nasional Majelis Ulama Indonesia (DSN-MUI) dengan dikeluarkan fatwa No. 107/DSN-MUI/X/2016 tentang Pedoman Penyelenggaraan Rumah Sakit Berdasarkan Prinsip Syariah. Salah satunya Rumah Sakit Sari Asih Sangiang (RSSA) yang berada di Kota Tangerang, telah mendapatkan sertifikasi syariah sejak tahun 2018. Salah satu pedoman utama dalam prinsip syariah di rumah sakit mengatur tentang Standar Pelayanan Minimal Syariah (SPM) Syariah yang meliputi membaca basmalah pada saat pemberian obat dan tindakan, hijab untuk pasien, mandatory training untuk fiqih pasien, adanya edukasi Islami, pemasangan EKG sesuai gender, pemakaian hijab ibu menyusui, pemakaian hijab di kamar operasi, dan penjadwalan operasi elektif tidak terbentur waktu sholat. Penelitian ini menggunakan pendekatan kualitatif melalui telaah dokumen laporan kegiatan pelaksanaan indikator mutu syariah yang formatnya ditetapkan dnegan checklist, survey, dokumen rekam medis, rekapitulasi sensus harian, bulanan dan tahunan, data sekunder dari penelitian sebelumnya, dan literatur terkait serta wawancara mendalam dengan kriteria koresponden adalah penangung jawab pelaksana Mutu Syariah di Rumah Sakit Sari Asih Sangiang. Hasil penelitian menunjukkan bahwa Rumah Sakit Sari Asih Sangiang sudah melaksanakan SPM Syariah dengan optimal yang implementasinya mengacu pada standar dan pedoman penyelenggaraan rumah sakit syariah yang dikeluarkan oleh DSN-MUI, namun masih terkendala dalam hal pencatatan. Saran yang diajukan adalah perlunya pembinaan dan pelatihan Sumber Daya Manusia, serta adanya pencatatan yang lebih teratur dalam rangka memaksimalkan target pencapaian.

Kata kunci: Implementasi; Standar Pelayanan Minimal Syariah; Rumah Sakit. 


\section{INTRODUCTION}

Indonesia is a muslim-majority country. About $87 \%$ of its 258 million people are muslims. ${ }^{1}$ Decentralization policy for regional governments creates autonomy for regions to be able to make their Local Regulations (Perda), one of which is Local Sharia Regulation. Data shows that at least 174 of the 508 districts in 29 provinces in Indonesia have adopted sharia regulations. $^{2}$

Sharia is Allah (God) provisions which is given to His servants, regarding the aqidah, worship, morals, and muamalah. ${ }^{3}$ Islamic Sharia Enforcement includes efforts to apply Islamic teachings in all aspects of life, including health. Caring for sick patients in sharia way should be a reference for every Muslim as the Allah Word in the Quran, Al Jathiyah (45) verse 18, "Then We put you, [O Muhammad], on an ordained way concerning the matter [of religion]; so follow it and do not follow the inclinations of those who do not know." 4

Sharia hospitals have begun to established in Indonesia since the Fatwa of the National Sharia Council of Majelis Ulama Indonesia (DSN-MUI) Number 107 of 2016 regarding "Guidelines for Implementing Hospitals Based on Sharia Principles" in 2016. These guidelines produce Minimum Service Standards and Sharia Quality Standards compiled by the Indonesian Islamic Health Service Assembly (MUKISI) through Decree Number 4 of 2016. This study aims to analyze the results of the minimum Sharia service standard implementation at Sari Asih Sangiang Hospital, which has obtained a Sharia Hospital certificate since 2018.

\section{Policy Implementation}

According to Edwards III (1980) in the "Direct and Indirect Impact on Implementation" model, policy implementation is influenced by four interconnected variables, which are: ${ }^{5,6,7}$

1. Communication. Policy decision or implementation regulation should be transmitted to the right implementor, with taking transmission, clarity, and consistency into account.

2. Resources. Policy implementation needs to be supported by employees who are sufficient and competent, not only in their fields, but also in information systems, authority, and facilities.

3. The attitude of an executor. In order to make a policy effective, the implementers of the policy must have the ability to execute, commit, be honest with the policy, and to perform democracy.

4. Organizational structure. Complex policies need teamwork and proper coordination in the organizational structure.

\section{Sharia Hospital Services Stipulation}

Sharia hospital is a hospital in which its management is based on the elements of aqeedah and sharia which are carried out under the teachings of Islam, and become part of the lessons and moral practices for hospital services. ${ }^{8}$ The sharia principle, which starts to be implemented to hospital regulation, is regulated in a fatwa (the opinion of the ulema and mufti) of the MUI. There are two fields of the fatwa that have a broad impact on society, which is halal food products and sharia economy. One of sharia's economy fatwa beside banking regulation is the sharia hospital regulation. ${ }^{9}$

Through DSN-MUI Fatwa Number 107 of 2016 point number five, the implementation of hospital services based on Sharia principles should follow the requirements which are: ${ }^{10}$

1. The Hospital and all responsible parties must fulfill the rights and obligations of each party.

2. Hospitals must provide services that always follow Clinical Practice Guidelines, clinical pathways, and service standards.

3. Hospitals must prioritize humanitarian aspects in providing health services that fulfil the needs of patients, regardless of race, ethnicity, and religion.

4. Hospitals must always commit to being trustworthy, polite, and friendly, and always strive to provide transparent and excellent quality services.

5. Hospitals must prioritize aspects of justice, and fairness in making calculations of costs that will be charged to patients.

6. Hospitals are required to provide religious services and consultations that are fit for the patient's recovery needs.

7. Patients and their Persons in Charge must comply with all regulations and procedures applied in the hospital.

8. Hospitals, patients and health workers in charge of the patient should show good morals and ethics (akhlak karimah).

9. Hospitals must avoid the acts of immorality, risywah, zhulm, and things that are contrary to the sharia.

10. Hospitals must have a Sharia Supervisory Board.

11. Hospitals must follow and refer to the fatwa of the Indonesian Ulema Council for things that are related to contemporary Islamic legal issues in the medical field (al-masa'il al-fiqhiyah al-waqi 'iyah althibbiyah).

12. Hospitals must have guidelines related to the procedures for worship that must be carried out by Muslim patients (i.e. procedures for purification and prayer for the sick).

13. Hospitals must have guidelines about hospital hygiene standards.

The implementation of sharia hospital is manifested in the application of Islamic principles in the way of thinking and practice the good deed in life. Shari'a benchmarks make every Muslim individual able to 
distinguish clearly and explicitly whether or not an activity or activity that he will do hopes to reach the blessing of Allah SWT. ${ }^{11}$

\section{Minimum Service Standards of Sharia Hospital}

MUKISI compiled the Minimum Service Standards of Sharia Hospital (SPM Syariah) as a tool to gather Islamic health facilities providers and individuals who have the expertise and interest to develop Islamic health service. SPM Syariah regulates matters concerning the care of the patient's faith during illness, facilitation of worship for the patient, safeguarding the patient's hijab, maintaining ikhtilath or separating male and female patients. Another regulation from SPM Syariah is the hospital's obligation to improve the competence of human resources in guiding, educating, and engaging patients to carry out worship while undergoing examinations and treatment at the hospital. ${ }^{12}$ Sharia hospitals provide health services that are under sharia principles and apply maqasid sharia in hospital governance. ${ }^{13}$

Maqashid in language origins is a form of maqshud, it derivates from word qashada which means heading, aiming, desiring, and intentional. ${ }^{9}$ Maqasid Sharia is the purpose of the laws which Allah SWT and His Messenger give to his servants to create benefit for the people. ${ }^{9,13}$ The implementation of Maqasid Sharia in the hospital, done by applying spiritual assessment for patients, gives more excellence compared to other hospitals that have not been applying sharia principles. $^{13}$ Ash-Syatibi formulates five maqasid sharia in Islam, which are: preserve religion, nurturing the soul, nurturing the mind, nurturing offspring, and maintaining wealth. ${ }^{14}$

Minimum Service Standards for Sharia Hospitals are the minimum service standards provided to patients related to the patient's spiritual service at the Hospital. There are 8 (eight) indicators of SPM for Sharia Hospitals that are: ${ }^{12}$

1. Reading Basmalah at the time of drug administration and medical procedure.

2. Hijab for patients.

3. Mandatory training for patient's fiqh.

4. Providing Islamic education (leaflets or spiritual books).

5. The gender-based operator-patients for ECG.

6. Hijab for nursing mothers.

7. Hijab in the operating room.

8. Scheduling elective surgery not to be constrained by prayer times.

Unlike SPM Syariah, Minimum Service Standards in the general health sector include standards in health services for mothers, infants, children, elderly, and other patients (hypertension, diabetes mellitus, mental disorders, tuberculosis, and HIV) without including elements of spiritual service in it.

\section{METHODS}

This study is a case study of Sharia Hospital Minimum Service Standards in 2018, conducted at Sari Asih Hospital (RSSA) Sangiang in Tangerang City. The qualitative approach is made by thorough reviews of the 2018 SPM Sharia Indicator achievement, in-depth interviews with the person in charge of the Service Quality and Patient Safety Committee (PMKP), and secondary data that relevant as indicator achievement (survey/checklist results, reports, receipt of books from patients or families of patients, registers for outpatient and inpatient procedure, and registers elective surgery schedules).

Each SPM Sharia Indicator is targeted to be achieved by $100 \%$ as an evaluation material, except in the mandatory training for the patient's fiqh and not constraining elective surgery with prayer times that only required to reach $80 \%$. Indicator measurements are calculated by the numerator formula (subjects that achieved the SPM) and the denominator (the total subject being the SPM target) that describes the value of each indicator. ${ }^{12}$ Target achievement data is collected once a month and will be analyzed every three months, except for mandatory training for the patient's fiqh, where collecting data is done every six months and analyzed every year.

\section{RESULTS}

Table 1. Basmallah reading, hijab for patient, islamic education, gender-based operator-patients for ECG achievement.

\begin{tabular}{llcc}
\hline Indicator & \multicolumn{1}{c}{ Unit } & $\begin{array}{c}\text { Percentage } \\
(\%)\end{array}$ & $\begin{array}{c}\text { Total } \\
(\%)\end{array}$ \\
\hline Basmallah & IGD & 100 & \\
reading & ICU & 98,3 & \\
& Surgery & NA & \\
& OBGYN & 98,7 & \\
& General & 97.1 & \\
& healthcare & 100 & 97,9 \\
& Child & 99,1 & \\
& healthcare & NA & \\
& Perinatology & 100 & \\
& Polyclinic & & \\
& Hemodialysis & & \\
\hline
\end{tabular}




\begin{tabular}{|c|c|c|c|}
\hline $\begin{array}{l}\text { Hijab for } \\
\text { Patient }\end{array}$ & $\begin{array}{l}\text { IGD } \\
\text { ICU } \\
\text { Surgery } \\
\text { OBGYN } \\
\text { General } \\
\text { healthcare } \\
\text { Child } \\
\text { healthcare } \\
\text { Perinatology } \\
\text { Polyclinic } \\
\text { Hemodialysis } \\
\end{array}$ & $\begin{array}{c}91,8 \\
98,7 \\
\text { NA } \\
95,9 \\
93,9 \\
\text { NA } \\
\text { NA } \\
\text { NA } \\
99,3\end{array}$ & 94,4 \\
\hline $\begin{array}{l}\text { Islamic } \\
\text { education } \\
\text { (leaflet } \\
\text { and } \\
\text { spiritual } \\
\text { book) }\end{array}$ & $\begin{array}{l}\text { IGD } \\
\text { ICU } \\
\text { Surgery } \\
\text { OBGYN } \\
\text { General } \\
\text { healthcare } \\
\text { Child } \\
\text { healthcare } \\
\text { Perinatology } \\
\text { Polyclinic } \\
\text { Hemodialysis } \\
\end{array}$ & $\begin{array}{c}100 \\
98,1 \\
\text { NA } \\
97,2 \\
95,9 \\
97,3 \\
66,6 \\
\text { NA } \\
100\end{array}$ & 97,5 \\
\hline $\begin{array}{l}\text { The } \\
\text { gender- } \\
\text { based } \\
\text { operator- } \\
\text { patients } \\
\text { for ECG. }\end{array}$ & $\begin{array}{l}\text { IGD } \\
\text { ICU } \\
\text { Surgery } \\
\text { OBGYN } \\
\text { General } \\
\text { healthcare } \\
\text { Child } \\
\text { healthcare } \\
\text { Perinatology } \\
\text { Polyclinic } \\
\text { Hemodialysis }\end{array}$ & $\begin{array}{l}100 \\
100 \\
100 \\
100 \\
100 \\
\text { NA } \\
\text { NA } \\
100 \\
\text { NA }\end{array}$ & 100 \\
\hline
\end{tabular}

Basmallah reading before administering medication and doing a medical procedure (injection and infusion) is a habit that has been usually done by RSSA Sangiang employees even before the introduction of Sharia SPM. The implementation of saying basmallah was recorded in the emergency unit, ICU, midwifery unit, general and childcare unit, perinatology unit, hemodialysis unit but its target achievement is still below 100\% (Table 1). While saying basmallah in the emergency unit, surgery department, and polyclinic, the Basmallah reading operation was also already applied but not recorded.

The availability of Islamic educational media such as leaflets or spiritual books for Muslim patients in the Inpatient unit (ICU, Midwifery, General and Child Care, and Perinatology) has been implemented but has not reached the maximum target. The emergency unit and hemodialysis unit have records that reach the target of $100 \%$ (Table 1). Leaflets or spiritual books are not given to outpatient units (Polyclinics) while receiving Islamic education is not feasible for patients in the operating room.

Gender-based operator-patient ECG installation is only cdone in units using ECG examinations such as ED, ICU, Surgery Unit, General Care, and Polyclinic. The achievement target for each unit has reached $100 \%$ (Table 1). Male patients are allowed to have an ECG by a female nurse while wearing a handscoon with family companion. ${ }^{16}$ In the childcare unit, Perinatology, and Hemodialysis unit, ECG installation is not needed.

Table 2. Hijab for Nursing Mother and Patient in Operating Room Achievements.

\begin{tabular}{llcc}
\hline \multicolumn{1}{c}{ Indicator } & \multicolumn{1}{c}{ Unit } & $\begin{array}{c}\text { Percentage } \\
(\%)\end{array}$ & $\begin{array}{c}\text { Total } \\
(\%)\end{array}$ \\
\hline Hijab for & Midwifery & 97.9 & 97,1 \\
Nursing & Surgery Unit & 100 & \\
Mother & Perinatology & 95,3 & \\
& Unit & & \\
\hline Hijab for & Midwifery & 96.5 & 96.5 \\
Patient in & Surgery Unit & & \\
Operating & Perinatology & & \\
Room & Unit & & \\
\hline Source: Laporan Pencapaian Indikator SPM Syariah
\end{tabular}

Source: Laporan Pencapaian Indikator SPM Syariah RSSA Sangiang, 2018

Hijab for nursing mothers aims to cover the breast when breastfeeding by using a hijab designed explicitly for breastfeeding that has an opening in the breast section. The use of Hijab in the operating room is done to be able to cover the patient's aurat during surgery. However, based on the results, the two indicators still have not reached $100 \%$ (Table 2).

Table 3. Mandatory Training for Patient's Fiqh and Scheduling elective surgery not to be constrained by prayer times achievement.

\begin{tabular}{|c|c|c|c|}
\hline Indikator & Unit & $\begin{array}{c}\text { Percentage } \\
(\%)\end{array}$ & $\begin{array}{c}\text { Total } \\
(\%)\end{array}$ \\
\hline $\begin{array}{l}\text { Mandatory Training } \\
\text { for Patient's Fiqh }\end{array}$ & $\begin{array}{l}\text { SDI } \\
\text { ICU } \\
\text { RPU }\end{array}$ & $\begin{array}{c}97,7 \\
100 \\
99,6\end{array}$ & 98,1 \\
\hline $\begin{array}{l}\text { Scheduling elective } \\
\text { surgery not to be } \\
\text { constrained by } \\
\text { prayer times }\end{array}$ & $\begin{array}{l}\text { Surgery } \\
\text { Unit }\end{array}$ & 100 & 100 \\
\hline
\end{tabular}

Source: Laporan Pencapaian Indikator SPM Syariah RSSA Sangiang, 2018.

Fiqh mandatory training for patients is mandatory for all RSSA Sangiang employees. This training aims to improve working skills and abilities, especially about thaharah /purification, talqin guidance, prayer guidance and hijab for patients. The scheduling of elective operations aims to ensure that the operation does not coincide with the prayer times of the doctor or the officer in the operating room. ${ }^{16}$ The targets of these two indicators have been fulfilled which is above $80 \%$ (Table 3). 


\section{DISCUSSION}

Sari Asih Hospital (RSSA) Sangiang, a type C private hospital in the city of Tangerang, is one of the branches of the Sari Asih Group Hospital that has received sharia certification in 2018. RSSA Sangiang has been trying to consistently apply the Islamic concept in its daily life at the hospital. Islamic nuances that have been shown before the introduction of sharia certification are the choice of dress, work ethics, routine recitation activities, the availability of halal medicines and halal food menus for patients and employees, but not yet applied to management and services in hospitals. Sharia certification makes RSSA Sangiang more comprehensive in guiding the implementation of sharia in their activities through the assessment determined by the DSN-MUI.

The National Sharia Council (DSN) is a council formed by the Indonesian Ulema Council (MUI) to deal with issues relating to Islamic Financial Institutions and implementation of Islamic values in economic activities, in this case, such as akad activities and muamalah in the hospital. DSN is the only body that has the authority to issue fatwas regarding the sharia activities, products, and financial services as well as oversee the application of these fatwas by various institutions that implement the fatwa in Indonesia. One of the fatwa is the DSN-MUI Fatwa No. 107 of 2016 concerning Guidelines for Implementing Hospitals Based on Sharia Principles.

Hospital Minimum Service Standards (SPM) are essentially guidelines for every type of hospital service that must be obliged by both government hospitals (provinces/cities/districts) and the private hospital with predetermined performance standards. SPM is used for hospital managers to determine how to plan, finance, and perform each type of hospital service.

In the implementation of Sharia SPM in RSSA Sangiang, three of the eight indicators have met the target during 2018. The three indicators that have reached the target are mandatory training for patient's fiqh $(98,1 \%)$, scheduling elective surgery not to be constrained by prayer times (100\%), and gender-based operator-patients for ECG examination (100\%). The implementations of the other five indicators are still below the target of $100 \%$, but the average implementation is above $90 \%$.

According to Edward III, four processes that influence policy implementation are communication, resources, attitude, and organizational structure that can determine the success of policy implementation. ${ }^{5,7}$ Indicators of successful communication are excellent communication in order to avoid miscommunication, clear and unambiguous communication received by policymakers (street -level-bureaucrats), and consistency in giving orders to avoid confusion. Successful implementation of Sharia SPM can be assessed by the perspective of the process and results.The well-implemented process is a process that in accordance with the instructions and implementation provisions made by the program maker, which includes procedures or implementation procedures, implementing agents, target groups, and program benefits. While in the results perspective, the program will be considered successful if it can bring the desired effect, such as the 2018 implementation that can be said to be optimal even though it has not fully reached the $100 \%$ target.

Information on the application of Sharia SPM in the RSSA Sangiang environment has been distributed by the Service Quality and Patient Safety Committee (KMKP) to the employees through fiqh training and Islamic education media (leaflets or spiritual books) to patients. Using educational media can provide the accuracy and consistency of the information provided. In previous studies, ideal interpersonal communication is when services provided to users were well received and got a positive or negative response. ${ }^{17}$

In terms of resources, implementers have been adequately provided with figh training. The indicators in resources are staff need to have the expertise and ability so that they can be competent in implementing policies; executor needs to be obedient to the Sharia SPM, and formal authority can become legitimacy for the policy executor. The entire employee of the hospital need to be a Muslim, and women need to be the majority of employees in RSSA Sangiang so that implementation related to gender and guarding the patient's aurat, such as during ECG examination and the use of hijab can be done well. Employees need to be trained, empowered and motivated for successful transitions to the lean culture or focused on increasing the capacity and organizational culture for continuous improvement. ${ }^{18}$ Management needs to understand that focusing on goals and implementing lean can improve health care outcomes. The head of the nursing unit at the RPU (General Treatment Room) said "Nursing HR follows a routine schedule of fiqh training or mandatory training with a 20 hours target with a duration of 2-3 hours of each meeting to increase their knowledge to educate patients" in the interview. This is in line with previous studies stated that each nurse in charge is provided with training and understanding the concept of guidance for the patients who should perform worship in order to be able to support the effectiveness of the application of sharia in hospitals. ${ }^{19}$

In terms of attitude, the executors are dedicated and well-aware of the importance of each indicator because it is part of Islamic teachings that need to be implemented and a manifestation of good morality. Every step and action that brings good to humanity must be considered and given support.20 Moral 
improvements such as greeting, saying basmalah and hamdalah while on duty; especially when examining patients; can improve patients satisfaction towards sharia-based hospitals.19 Ustadz and ustadzah always need to be ready to guide spirituality for employees and patients, and ecclesiastic in other religions is also provided to respect other religions. Mandatory training is done by providing the employees and staff the training of understanding and meeting the patient's spiritual and fiqh needs. The material in mandatory training includes guidance on thaharah/purification, talqin guidance, prayer guidance and hijab for (women) patients in the hospital. ${ }^{9}$

The RS has committed to implement sharia with establishing Sharia Supervisory Board (DPS), as required by the DSN-MUI. DSN-MUI recommendations are given to appoint DPS in sharia hospitals which are then appointed by hospital owners to be responsible for overseeing all hospital operations based on sharia principles. The function of DPS is not only to supervise but also to solve all issues with discussion in sharia way, education, socialization to the public, issuing sharia opinions, reporting services and operations from the sharia side to RS owners and DSNMUI. $^{9}$

Service Quality and Patient Safety Committee through the person in charge of each unit implements SOPs (Standard Operating Procedures) and daily supervision. The sharia supervisory committee in the hospital is a group of people consisted of Islamic law experts and a group of medical specialists who are responsible for monitoring and supervising the application of Islamic law related to medical practice to be obeyed and practiced in the hospital.20 In the certification assessment, a hospital first must pass hospital accreditation by KARS. KARS accreditation and sharia certificates would make hospitals more qualified and superior in ensuring safety and patient service quality. $^{21,22}$ Maqasid Sharia in sharia-based hospital services is also influential and has a relationship with patient/community interests and preferences towards Islamic hospital. $^{14}$

Overall the implementation of Islamic SPM has met the optimal target, but it still has some issues regarding data recording for reporting its implementation, especially in the HR of nursing units which are directly related to health services to patients. Based on the interview results with the SSMM team (Quality Management Sharia Standards), it is known that the reason why SPM sharia has not yet optimally met the target is due to the lack of regular data recording. The indicators that have been implemented are sometimes not recorded by the implementers.

\section{CONCLUSION}

Sharia standards in hospitals, determined by policies and quality guidelines regulated in the DSN-MUI fatwa, aimed to maintain aqeedah, worship, morals, and muamalah according to the Al-Quran and AlHadist. Based on the results of the evaluation, the implementation of Sharia SPM in RSSA Sangiang in 2018 has achieved optimal service targets. This achievement of Sharia SPM in RSSA Sangiang should be maintained and improved in the future. Through review of documents and interviews, obstacles in achieving targets are due to the irregular recording of implementation data, hence there is a need for training of HR in the nursing unit to be more discipline at reporting and recording.

We suggest Suggestions are given in an effort to improve the implementation of Sharia SPM by managing and fostering human resources related to the medical service unit in the hospital and conducting monitoring and evaluation of implementation with more regular records in each health service unit

\section{REFERENCE}

1. Badan Pusat Statistik. Tabel Data Sensus Penduduk 2010: Penduduk Menurut Wilayah dan Agama yang Dianut. 2010. BPS. https://sp2010.bps.go.id/index.php/site/tabel?tid=3 21\&wid=0. Diakses 30 April 2019.

2. Muhtada, D. The Mechanism of Policy Diffusion: A Comparative Study of Shari'a Regulations in Indonesia. A Dissertation For The Degree Doctor of Philosophy. Proquest LLC. United States. 2014.

3. Rohidin. Buku Ajar Pengantar Hukum, dari Semenanjung Arabia hingga Indonesia. Yogyakarta: Lintang Rasi Aksara Books. 2016.

4. Kementrian Agama Republik Indonesia. AlQuranul Karim Terjemahan dan Tajwid. (Surakarta: Az-Ziyadah). 2014.

5. Ayuningtyas D. 2018. Analisis Kebijakan Kesehatan Prinsip dan Aplikasi. PT Rajagrafindo Persada. Depok. 2018.

6. Akib H. Implementasi Kebijakan: Apa, Mengapa, dan Bagaimana. Jurnal Administrasi Publik Vol 1 No.1. Universitas Negeri Makasar. 2010.

7. Arief S., Jumadi, Abdullah. Pengembangan Model Implementasi Kebijakan Program Penanganan Anak Jalanan untuk Pengentasan Kemiskinan di Kota Makassar. Seminar Nasional. Makasar. 2016.

8. Sari D.W.P., Abdurrouf M., Rismawati. Pelayanan Keperawatan Berbasis Syariah dan Loyalitas Pasien di Rumah Sakit Islam. Jurnal Keperawatan dan Pemikiran Ilmiah Sari Vol. 4, No. 7 : 109-117. Nurscope. Fakultas Ilmu Keperawatan. Universitas Islam Sultan Agung Semarang. Jawa Tengah. 2018. 
9. Linda T.M. Implementasi Fatwa DSN-MUI No.107/DSN-MUI/X/2016 Tentang Pedoman Penyelenggaraan Rumah Sakit Berdasarkan Prinsip Syariah Di Rumah Sakit Islam Klaten. Skripsi Jurusan Hukum Ekonomi Syariah (Muamalah). Fakultas Syariah Institut Agama Islam Negeri (IAIN). Surakarta. 2019.

10. Fatwa Dewan Syariah Nasional Majelis Ulama Indonesia No 107 Tahun 2016; Pedoman Penyelenggaraan Rumah Sakit Berdasarkan Prinsip Syariah. DSN-MUI. Jakarta. 2016.

11. Harahap S. Implementasi Manajemen Syariah Dalam Fungsi-Fungsi Manajemen. Jurnal AtTawassuth, Vol. 2, No.1 : 211-234. Fakultas Ekonomi dan Bisnis Islam. Universitas Islam Negeri Sumatera Utara. Medan. 2017.

12. Majelis Upaya Kesehatan Islam Seluruh Indonesia. Pedoman Standar Pelayanan Minimal Rumah Sakit Syariah dan Indikator Mutu Wajib Syariah. Mukisi. Jakarta. 2017.

13. Sulistiadi W.S., dan Rahayu S.R. Potensi Penerapan Maqashid Syariah Dalam Rumah Sakit Syariah di Indonesia. Proceeding IAIN Batusangkar, 1(1). 683-690. 2017.

14. Firdaus F.A., Nafik M. Analisis Preferensi Masyarakat Terhadap Maqasid Syariah Islamiyah yang Diterapkan pada Rumah Sakit Islam di Surabaya. Jurnal Ekonomi Syariah Teori dan Terapan Vol. 5 No. 3: 169-83. Maret 2018.

15. Moelok N. F. Peraturan Menteri Kesehatan Republik Indonesia Nomor 43 Tahun 2016 tentang Standar Pelayanan Minimal Bidang Kesehatan. (Berita Negara Republik Indonesia Tahun 2016 Nomor 1475: Jakarta). 2016.

16. Anonymous. Standar Prosedur Operasional, Standar Pelayanan Minimal Syariah. RSSA Sangiang. Tangerang. 2018.

17. W.A. Agung N. The Impact of Interpersonal Communication Toward Customer Satisfication: The Case of Customer Service of Sari Asih Hospital. Matec Web of Conference 150, 050807(2018). Jakarta. 2018.

18. Grijalva P., Eseonu C. A Tool To Asses Continous Improvement Culture : Adapting Servqual Scale to Measure Employee Satisfaction, and Identify Factors of Success. Proceeding of the American Society for Engineering Management 2016 International Annual Conference S.Long, E-H.Ng, C. Downing, \& B. Nepal eds. Oregon State University. 2016.

19. Helida N. Efektivitas Pelayanan Berbasis Syariah Terhadap Kepuasan Pelanggan pada Sektor Layanan Publik (Studi Kasus: RSUD dr.Zainoel Abidin Kota Banda Aceh). Skripsi Program Studi Ekonomi Syariah. Fakultas Ekonomi dan Bisnis Islam Universitas Islam Negeri Ar-Raniry Darussalam. Banda Aceh. 2018.
20. Samsudin M.A, et al. The Concept of Establising a Syariah Supervisory Committee in Malaysian Hospital. Journal Procedia Social and Behavioral Sciences. Vol. 174 (2015) 1202-1206 Elsevier. Malaysia. 2015.

21. Ismail S.A., et all. Journey to Shariah Hospital: An Indonesian Experience. International Journal of Human and Health Sciences.Vol.02 No.02 April 2018.

22. Sulistiadi W.S., dan Rahayu S.R. Assesment of First Sharia Hospital Certification in Indonesia Facing The Global Competition. Batusangkar International Conference 99.301-304. 2017. 